\title{
Strategy for the Development of Tourism Objects of Situ Cisanti, Kertasari Regency in the Department of Tourism and Culture of West Java Province
}

\author{
Yaya Mulyana Abdul Aziz*, Isnania Meilawati Sekarwulan \\ Faculty of Social and Political Science \\ Pasundan University \\ Bandung, Indonesia \\ *mulayana_yaya@unpas.ac.id, isnania113@gmail.com
}

\begin{abstract}
This study begins with the problems associated with the development strategy attractions in Situ Cisanti, Kertasari at the Department of Tourism and Culture of West Java Province, namely, $\mathrm{m}$ compassionate presence of West Java community who do not know and understand about Situ Cisanti, from the beginning of history Situ Cisanti and the petition. This study uses indicators in accordance with Hardinoto. The purpose of this study was to determine the development of tourism objects in Situ Cisanti so that this tour could develop well and attract more and more people, both the people of West Java and outside West Java. An attraction that is still less influenced by factor of promotion and marketing of Tourism and Culture West Java, so that researchers can provide helpful suggestions for the continuation of the construction improvement Situ Cisanti on Culture and Tourism Department of West Java Province. The method used in this research is descriptive qualitative with field study data collection techniques by means of observation, interviews, and documentation studies. Based on the results of the study, it is shown that the Wana Situ Cisanti Tourism Object Development Strategy, Kertasari Regency at the Tourism and Culture Office of West Java Province needs to be further improved so that it can continue to develop properly in fulfilling the elements of the development strategy steps proposed by Hardinoto namely Attraction Tourism (Natural Resources, Human Resources and Cultural Heritage), Promotion and Marketing, Tourism Markets (Tourism sending community), Transportation, Society.
\end{abstract}

Keywords—tourism, development strategy, Cisanti Lake

\section{INTRODUCTION}

West Java is one of the regions in Indonesia with amazing tourist destinations, the tourist attractions of West Java Province are very diverse. Natural, cultural, and artificial tourism are spread in the West Java region, with unique local characteristics that strengthen the competitiveness of West Java tourism products. The government agency that handles the tourism sector is the Department of Tourism and Culture (DISPARBUD) of West Java Province. The West Java Province Tourism and Culture Office is a government agency responsible for culture and tourism which includes the tourism industry, tourism and cultural destinations in West Java Province. One of the tourist destinations that is being developed by DISPARBUD is Wana Wisata Situ Cisanti, Kertasari District.

Bandung Regency has very beautiful natural tourism and has interesting tourist destinations, not only natural tourism but also tourism such as culinary tourism, shopping tourism, to agro tourism. When viewed from the natural conditions surrounded by mountains, it certainly adds to the impression as a very interesting natural tourist destination to visit. Bandung Regency also has several alternative tourist destinations, one of which is Wana Wisata Situ Cisanti which is located in Tarumajaya Village, Kertasari District, Bandung Regency. Wana Wisata Situ Cisanti is one of the natural attractions in the south of Bandung City. Wana Wisata Situ Cisanti which features natural tourism with an attraction that comes from the beauty of nature and its environment. It is hoped that the Situ Cisanti Wana Tourism Object can be developed because it has natural beauty that is still beautiful, historic, and unique contained in it. So that the Situ Cisanti Wana Tourism Object can provide tourist attractions that are different from other tourist attractions.

Situ Cisanti is the headwaters of the Citarum river which is the longest river in West Java. Cisanti Lake is a lake that was formed about 500 years along with the existence of the Citarum River. The origin of the name Cisanti comes from a beautiful Dutch woman who often bathes in Situ Cisanti. Situ Cisanti is only about 10 hectares wide and has a depth of only 1.5 meters. The water in Situ Cisanti is not too clear and a bit greenish, there is a lot of green moss so many residents use the moss to sell it to anglers. In February 2018 the Situ Cisanti area was cleared by members of the TNI in collaboration with the manager of the Situ Cisanti area, namely Perum Perhutani in the South Bandung area. The cleaners in the Situ Cisanti area also planted carp seeds to beautify the Situ Cisanti area. So that the water in the Situ Cisanti area is now quite clear, even the fish are clearly visible to the naked eye. The manager also 
issued a regulation that there should be no fishing activities in Situ Cisanti and a regulation not to bring food into the Situ Cisanti area so as not to litter.

Situ Cisanti is a lake which is one of the tourist attractions that is guarded by Perum Perhutani of Bandung Regency called Situ Cisanti Tourism, Wana Wisata Situ Cisanti is a strategic area of the province managed by Perum Perhutani KPH South Bandug and the Village Community of Lembang Forest (LMDH) Tarumajaya. The location of Situ Cisanti Wana Wisata is in Tarumajaya Village, Kertasari District, Bandung Regency. Situ Cisanti comes from 7 springs which are believed to have different properties, the springs include Cikahuripan (Pangsiraman), Cisadane, Cikaludan, Chaniwung, Cikawadukan, Cikolebere, and finally Cisanti. The spring is considered sacred and is considered capable of fulfilling the requests of pilgrims where there is also the Dipati Ukur Petilasan Site so that not a few visitors come for pilgrimage purposes at Cisanti Lake.

Situ Cisanti has the main benefit, namely as a source of Citarum river water which is a source of livelihood for the people of West Java, especially as the main supplier of water needs for the Tarumajaya Village area. The benefit from an ecological perspective is as a habitat for plants and animals around and in it. From an economic point of view, it is a tourist place because in these tourist attractions there will be an economic implementation, where local people can sell food, drinks and so on. Situ Cisanti is also beneficial for the surrounding community, apart from being a business actor as well as a tourism actor, where Cisanti Lake can be an alternative resting place for the surrounding community. Based on these conditions, researchers are interested in conducting research on the Strategy for Development of Situ Cisanti Tourism Objects in Kertasari Regency at the Tourism and Culture Office of West Java Province.

\section{METHODS}

Substantive, research methods tend to indicate the type or research model that will be used by researchers. The model or type that the researcher will use is descriptive qualitative. Sugiyono [1] stated that descriptive research was conducted to obtain objective, valid, and variable data, with the aim of being able to find, provide, and develop knowledge, so that in turn it can be used to understand, solve, and anticipate problems in administration. Meanwhile, the data collection technique used by the researcher is through interviews, literature review which will be carried out to facilitate the analysis of the problem [2].

\section{RESULTS AND DISCUSSION}

The Department of Tourism and Culture of West Java Province continues to improve the strategy for developing tourism objects in West Java, especially in the Bandung Regency area. In accordance with the administration of government affairs in the field of tourism and culture which includes tourism destinations, the tourism industry, marketing and culture which are the authority of the Province, carry out deconcentration tasks and assistance tasks in accordance with their respective fields of duty based on the provisions of the legislation.

This study describes the results of research by the Tourism and Culture Office of West Java Province on the Strategy for Development of Wana Situ Cisanti Tourism Objects in Kertasari Regency at the Tourism and Culture Office of West Java Province. It is described using a qualitative method with an approach based on observations, documentation studies, and interviews that the researchers conducted with informants consisting of the Head of the Department of Culture, Tourism and Marketing, General Staff of Civil Servants related to the title of the researcher.

The Citarum River, which originates at Situ Cisanti, Kertasari District, Bandung Regency, flows through 12 regencies/cities in West Java. Among them are Bandung Regency, West Bandung Regency, Bekasi Regency, Cianjur Regency, Indramayu Regency, Karawang Regency, Purwakarta Regency, Subang Regency, Sumedang Regency, Bandung City, Bekasi City, and Cimahi City. But who would have thought, this Citarum River has a very beautiful upstream and very clear water. The upstream location is in Situ Cisanti, namely in the Malabar Tea Plantation, Pangalengan. Situ Cisanti is also located at the foot of Mount Wayang. Because of its location at an altitude, Situ Cisanti has cool and fresh air, perfect for refreshing.

Besides playing an important role in the history and life of the people of West Java, Situ Cisanti also has views and facilities such as a bridge that can be used as a photo hunting place. In addition to photo hunting, other activities that can be done at Situ Cisanti are traveling around the lake by boat, and even camping. Situ Cisanti is located at the foot of Mount Wayang which is now part of the Perum Perhutani area. Not only that, his role is very important for the livelihood of the people of West Java. Situ Cisanti is one of the historical witnesses from the kingdom to the colonial era. The name of this article is:

Many say Situ Cisanti is like "the pulse of West Java" because Situ Cisanti is the headwaters of the Citarum River, the largest and widest river in West Java, which has a length of about $269 \mathrm{~km}$ and divides 12 districts and cities. Indeed, if we look at places where the water is not clean or clear, a lot of the water is black or green because it has been polluted by factory waste.

The people of West Java must know about the history of Mount Wayang and about tourism in Situ Cisanti which is still active today, many visitors come for tours, the Situ Cisanti area was officially inaugurated in 2003 when the Governor of West Java at that time, Mr. Nuryana, reopened the environment for agricultural activities. in Tarumajaya Village and finally opened Cisanti Situ for structuring and reforestation. Mount Wayang is also said to have said there is a history that the people of West Java may not know about, at Mount Wayang there are statues of ancient relics but unfortunately the petilasan statues are not everywhere. 
Research on Strategy Development of Wana Situ Cisanti Tourism Object in Kertasari Regency at the Tourism and Culture Office of West Java Province was carried out because of the awareness of research on the importance of developing this tourist attraction so that it continues to develop properly. There are many people who have never played or know what Situ Cisanti is like so that the attraction of the community can be redeveloped, especially with the problem of the COVID-19 pandemic, all tourist attractions everywhere have a bad impact on the decline. in tourist places temporarily closed due to the high increase in Covid.

\section{DISCUSSION}

The elements of the development strategy steps proposed by Hardinoto [3] namely Attraction Tourism (Natural Resources, Human Resources and Cultural Heritage), Promotion and Marketing, Tourism Markets (Tourism sending community), Transportation, Society.

\section{A. Tourist Attractions (Natural resources, human resources and culture}

The definition of tourist attraction here is the attraction of tourists for vacation, development strategies in the form of natural resources, human resources, culture, information, whether everything has met or exceeded expectations [4]. Some natural resources are in Situ Cisanti namely: 7 springs that are very beneficial for the people of West Java and the surrounding communities, not only very important role for the source of life, Situ Cisanti is one witness to the history of tenure until the era of colonialism. The source of water in Cikahuripan springs is still natural because it comes directly from tree roots. In addition, the water source in this spring never decreases even in dry months. Not only that, it is believed that some residents have their own blessings in Cikahuripan springs. Not infrequently residents who visit the springs often take off their clothes and soak in the spring pool. Maybe for some people who think positively about these myths are very useful for preserving springs, which sometimes people damage if not feared by myths. However, some people think that these myths actually damage the faith of Muslims, and instead become wasilah (means) to commit polytheism.

As for Human Resources, there are many people who are excited to be active again in caring for Situ Cisanti because many are also taking care of it according to the program, namely Citarum Harum, so it is not surprising that there are many women, guards and the Siliwangi TNI and Sector 1 Task Force guarding the field. People also take advantage of this tourism as income. They can trade to open a business in Situ Cisanti environment, while those who use it to grow crops and garden at Mount Wayang, Windu and Mount Rakutak.

The culture around Situ Cisanti, the community still maintains and preserves it. Located at the end of the stone road, there is a place that was once said to be the bathing place of Prabu Siliwangi, the great king of the Sunda land. At the bottom of the spring there is a stone used by the king, it is said that there are even footprints and footprints that can still be found today. In spring, visitors are allowed to bathe and bathe but must adhere to established manners and procedures.

\section{B. Promotion and Marketing}

Promotion and marketing can mean that tourism objects also need to be advertised to be better known by the wider community [5]. This promotion aims to let the public know that this tour exists and is active. Whether it's through advertisements, social media or others, so that Situ Cisanti tourism will increase the number of enthusiasts who want to come because there is a lot of history and what we must know is the land. To carry out the function of tourism will require the development of object travel and power pull travel, improve and expand $\mathrm{k}$ 's promotion and marketing, as well as improving education and training of tourism.

Promotion is a design to introduce the tourist attractions offered and how these tourist attractions can be accepted by the public so they want to visit Cisanti Lake. Officers must also participate fairly in this promotion because there must be someone who guides what if those who come are given directions in the Cisanti environment so that the people who come are not confused. In order for Situ Cisanti tourism to develop well, especially from its attractiveness, now entering Situ Cisanti is comfortable with practical prices starting from the entrance ticket. To enter this tourist area, visitors do not need to spend too deep. Tickets are valid for adults only at affordable prices. Every agency related to Situ Cisanti, both management and development, can synergize well so that the promotion of Situ Cisanti tourism can be visited by more people from West Java and from outside the city. The government has never questioned the entrance fee, because their job is only to maintain and preserve the Cisanti and Citarum rivers so that visitors can come and not get bored.

So from the results of observations and analysis with research, maybe promotions should be increased in informing this tourist spot because along with the times, there should be a website for Situ Cisanti itself so that people can be interested in returning to Situ Cisanti. The price of the entrance ticket is actually quite cheap, the motorbike is only 25,000 thousand rupiah, with motorbike parking, visitors don't need to spend money anymore because they want a good tour and at the same time know the history of Situ Cisanti.

\section{Tourism Market}

People on land are very happy and can take advantage of the environment in Situ Cisanti because the land on the ground is still beautiful, so many people use the land for plantations such as leeks, carrots, broccoli and so on which are finally sent to various places, so that visitors who will coming to Situ Cisanti will be pampered with a very beautiful environment.

Not only using plantation products, there are also people who use this tour to sell, open roadside resorts and restaurants, people can spoil the beautiful scenery for visitors who come. to Situ Cisanti so as not to get bored on the road or bored because 
of a very long journey. However, there are several rest areas in Cisanti that are still not neat in taking care of it, even though many people who visit it bring lunches from home to eat with their families at Situ Cisanti, namely botram must always obey the rules by throwing garbage in its place. This shows that tourism became the backbone of community life, thus supporting facilities of tourism activity need for cooperation between governments and the private sector one market development of tourism, it is referred from the study [6].

If visitors who will come to the Tarumajaya Village area will meet on the side of the Pacet Ciparay road, there is a surprise market every Saturday morning until noon, they sell on the football field in the Pacet area which the majority sell Ciparay people who sell for daily needs.

\section{Transportation}

The distance to Situ Cisanti is about 45 kilometers from the center of Bandung, most of the roads to these tourist attractions are still smooth asphalt and concrete. Some roads are still ugly but only a short distance due to unfinished work. After undergoing various facility improvements, now the Situ Cisanti tourist attraction is more visitor-friendly. The parking area is spacious, there are rows of stalls and rest huts, toilets, prayer rooms, and a distribution of park benches around the lake area.

To come, visitors don't need to worry about alternative roads or vehicles because the roads on land are good, there are no potholes, it's just that when they arrive, they have to be patient, the journey is very long and a little difficult because there are many trucks. blocking the road carrying vegetables in transportation. plantations, not only good roads in the area of sanah, there is still public transportation that will lead us to the impression that only the road is slightly uphill and winding. The motorcycle taxi base on land will take us to Situ Cisanti until we reach our destination.

Not only alternative vehicles, but for lodging and swimming on every road, there are many vacation spots in the country that must be visited because they are quite close to Situ Cisanti, there are several lodging places such as villas and hotels.

\section{E. Society}

In the facilities and services in the field, the officers are very good when they come to the ticketing section, the officers tell about entrance tickets and so on, but in guiding people who have just arrived they are not guided or notified of the finished place. history although there are Satgar Sector 1 or TNI Siliwangi officers who surround the road to monitor visitors who come.

The community must change the mindset about the Citarum River which has been polluted by waste water, the Government and the community are now able to maintain and preserve Cisanti Lake, especially the river and its environment so that it can benefit us all well. Actually, just like Hulu Citarum, it still flows well with 7 springs flowing well too. Only this awareness, he said, is by changing the perspective of the people around the upper Citarum. The reason is that many residents use the land in the hills to plant vegetables which are considered less profitable for land security. For this reason, there needs to be a collaborative government that involves the government as the policy holder, the private sector as an investor and the community as users of the policies set by the local government [6]. So that with the policy of the order, it will have a significant influence in improving the living standards of the local community, which in the end will affect the welfare of the people who do not only live in the Situ Cisanti area but will also have more influence on the people around the Situ Cisanti area.

\section{CONCLUSION}

The existence of this tourist attraction makes many government agencies participate in maintaining Cisanti Lake, starting from how to take care of it, preserving the natural environment that is still beautiful and beautiful, the community also takes advantage of this tourism preservation. In developing this tour, the government is able to continue to develop this tour so that it is not empty of enthusiasts, there is a lot of history and history that must be developed again so that the attraction of enthusiasts increases. Although there are many competing tourist attractions, Situ Cisanti must be maintained so that the devotees do not lose.

A form of promotion to the public about this tour as much as possible should be able to promote all types of tourism in West Java. Moreover, in terms of tourism, there is no tourism promotion either in the form of advertising or social media itself. Someone has to manage it. Other tourist attractions are closed during the Pandemic because they have to take care of themselves with the current situation, which is being crowded by the Covid-19 Pandemic.

\section{REFERENCES}

[1] Sugiyono, Metodologi Penelitian Administrasi. Yogjakarta: CV Alfabeta, 1997.

[2] I. Satibi, Teknik Penulisan Skripsi, Tesis \& Disertasi. Bandung: CEPLAS, 2011

[3] K. Hadinoto, Perencanaan Pengembangan Destinasi Pariwisata Jakarta: Penerbit Universitas Indonesia, 1996.

[4] S. Sedarmayanti, Pembangunan \& Pengembangan Pariwisata. Bandung: Refika Aditama, 2018.

[5] Y. Mulyana and R.M.A. Huraerah, "Model Kebijakan Mixed Scanning dalam Pengembangan Pariwisata Cianjur Selatan," Dinamika Governance : Jurnal Ilmu Administrasi Negara, ISSN: 2303-0089, eISSN: 2656-9949, 2019

[6] Y. Mulyana and R.M.A. Huraerah, "Kebijakan Pengembangan Destinas Pariwisata Cianjur Selatan Di Kabupaten Cianjur Jawa Barat," Jurna Ilmu Sosial dan Ilmu Politik, vol. 9, pp. 490-511, 2019 